\title{
PODOCALLICHIRUS LAEPAENSIS, A NEW GHOST SHRIMP (CRUSTACEA, DECAPODA, CALLIANASSIDAE) FROM THE LATE MIOCENE OF SOUTHWEST SPAIN
}

\author{
MATÚŠ HYŽNÝ ${ }^{1}$ AND FERNANDO MUÑIZ² \\ ${ }^{1}$ Department of Geology and Paleontology, Faculty of Natural Sciences, Comenius University, \\ Mlynská dolina G1, 84215 Bratislava, Slovakia, <hyzny.matus@gmail.com>; and ²Grupo de Investigación RNM 316 “Tectónica y Paleontología," \\ Facultad de Ciencias Experimentales, Campus del Carmen, Universidad de Huelva Avda. Tres de Marzo, s/n, \\ 21071 Huelva, Spain, <gyrolithes@yahoo.es>
}

\begin{abstract}
Callianassids are among the most commonly found decapod crustacean fossils but their generic assignment is often difficult. Numerous cheliped remains have been found in the upper Miocene deposits of southwest Spain allowing description of a new species of a ghost shrimp, Podocallichirus laepaensis. The assignment of the new form to the respective genus is based mainly on the morphology of the major cheliped merus and provides useful implications for paleontological studies. Podocallichirus laepaensis is the first fossil record of the genus known to date. Several specimens preserved in association with and within Ophiomorpha traces are interpreted as in situ preservation. Thus, the new ghost shrimp is identified as the producer of trace fossils.
\end{abstract}

\section{INTRODUCTION}

$\mathrm{C}$ ALLIANASSIDAE DANA, 1852 is a distinct family of fossorial shrimps, classified within the superfamily Callianassoidea Dana, 1852. Members inhabit predominantly intertidal and subtidal marine environments of mainly tropics and subtropics (Dworschak, 2000, 2005) and exhibit sophisticated behavior involving digging complex burrow systems. They can rework huge amounts of substrate and are considered true ecosystem engineers (Tamaki, 2004).

Callianassoid shrimp remains are among the most commonly found decapod remains in the fossil record; however, because of the delicate structure of most cuticular surfaces, only chelipeds which are usually heavily calcified are likely to be preserved (Bishop and Williams, 2005). The biological classification of the Callianassidae is based mainly on soft part morphology with poor or no fossilization potential, thus the fossil material usually lacks the diagnostic characters of extant taxa. Manning and Felder (1991) turned attention to the characters on chelipeds, although they discussed extant American taxa only. The taxonomic importance of the chelipeds in systematics of callianassid genera was emphasized also by Ngoc-Ho (2003) when comparing genera within the subfamily Eucalliacinae Manning and Felder, 1991. Such studies are thus considered of great importance for paleontologists working with incompletely preserved individuals.

Material representing a new callianassid shrimp shows characters present in several genera of the subfamily Callichirinae Manning and Felder, 1991, notably Callichirus Stimpson, 1866, Neocallichirus Sakai, 1988, Sergio Manning and Lemaitre, 1994, Podocallichirus Sakai, 1999 and Glypturoides Sakai, 2011. Based mostly on the morphology of the merus of the major cheliped, the new form is assigned to the genus Podocallichirus. It constitutes the first callianassid taxon identified to species level from the late Miocene strata of Spain.

\section{GEOLOGIC SETTING AND STRATIGRAPHY}

The studied section named "Valleforero" (Muñiz, 1998) located in the surroundings of the town of Lepe (Huelva province, SW Spain) lies in the western sector of the Guadalquivir Basin (Fig. 1). This Neogene foreland basin describes an ENE-WSW elongated triangle with remarkable asymmetry. Its southern limit corresponds to the External
Zone of the Betic Ranges, while the northern passive margin is bounded by the Paleozoic basement of the Iberian Massif.

The origin of this basin is linked to the collision of the African and Iberian plates during the Neogene. This caused asymmetrical uplift of the sediments filling the basin and, as a consequence, the deposits of the easternmost side are now exposed at an elevation of more than $800 \mathrm{~m}$ above sea level, whereas the western end of the basin (opening to the Atlantic Ocean) was much less affected by tectonics (Sanz de Galdeano, 1990; Braga et al., 2003). During the Miocene and Pliocene, the northern passive margin and the center of the basin were filled with autochthonous and parautochthonous terrigenous and biogenic deposits, whereas the active south and southeastern margins were filled with allochthonous materials of the olistostrome structural unit (Sierro et al., 1996).

In the Huelva province, Neogene marine autochthonous sediments have been divided into four formally-defined formations, which from bottom to top are: 1) the Niebla Formation (Baceta and Pendón, 1999), also known as Basal Transgressive Complex (Pendón et al., 2004; Abad et al., 2005), the occurrence of Neogloboquadrina humerosa suggests a late Tortonian (late Miocene) age (Sierro et al., 1990); 2) the Gibraleón Clays Formation (Civis et al., 1987) is interpreted as upper Miocene (upper Tortonian, Turborotalia humerosa biozone sensu Sierro, 1985) and lower Pliocene (Globorotalia miotumida and G. margaritae biozones sensu Sierro, 1985); 3) the Huelva Sands Formation consists of a condensed basal level of glauconitic sandstone, with siltstone and fine sandstone above. Based on the occurrence of Globorotalia margaritae and G. puncticulata, this formation is interpreted as lower Pliocene (Sierro, 1985); and 4) the Bonares Sands Formation occurs at the top of the Neogene succession. Sierro et al. (1996) suggested an upper lower Pliocene age for this unit, although no definitive biostratigraphic data are yet available.

The 'Lepe White Silts' in the Lepe-Ayamonte area.-In the Lepe-Ayamonte sector of the Guadalquivir Basin, the Neogene sediments are represented by an array of marginal marine siliciclastic facies informally known as the 'Lepe White Silts' (Muñiz et al., 2010). This unit unconformably lies upon Lower Carboniferous graywackes and shales and it is unconformably overlain by lower Pleistocene sands, gravels and conglomerates interpreted as fluvial terrace deposits 


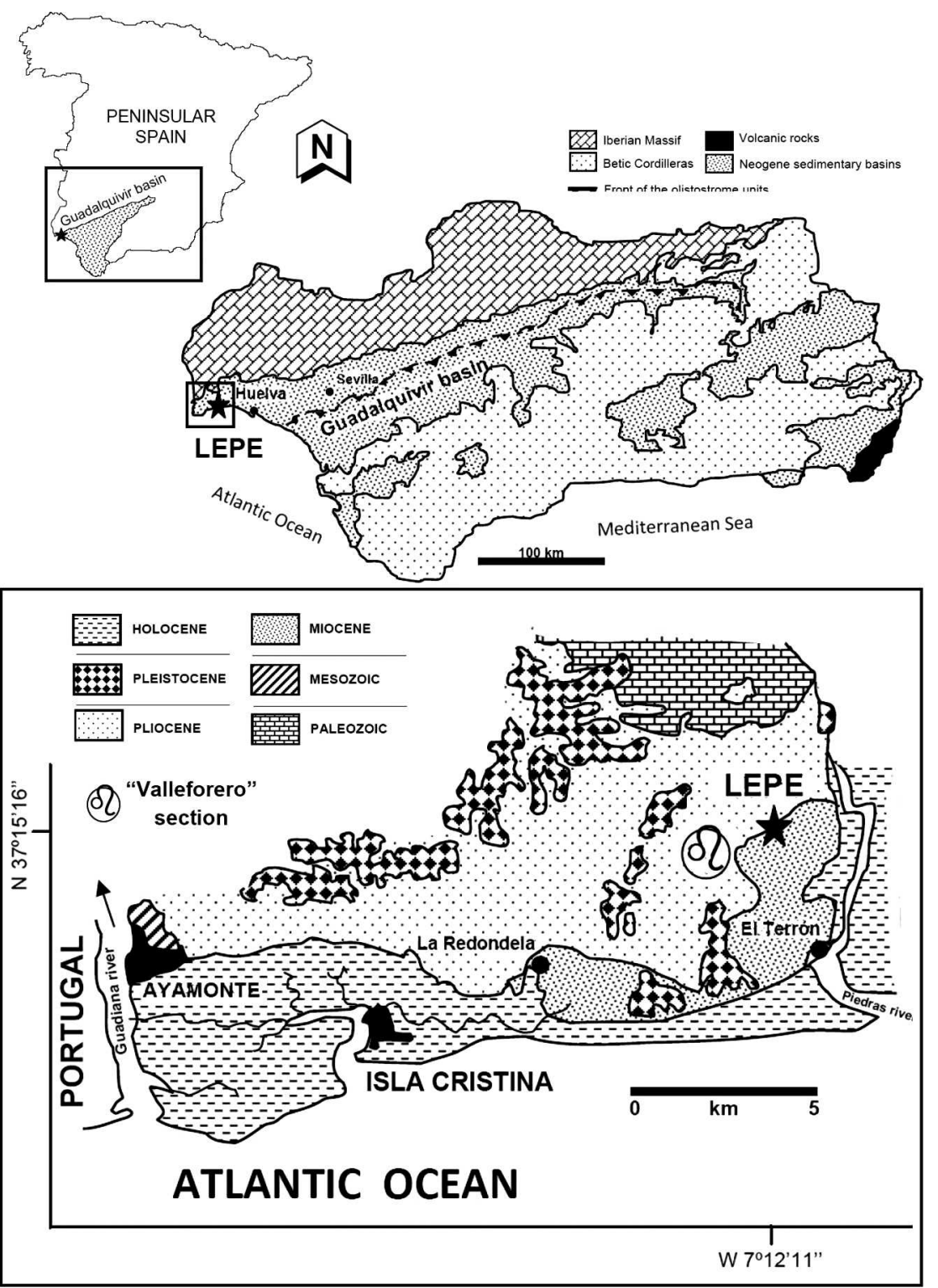

FIGURE 1 -Geographic position of the Guadalquivir Basin and surroundings of the town of Lepe. Podocallichirus laepaensis $\mathrm{n}$. sp. originates from the medium to coarse sands of the unit 5 (upper Miocene) of the "Valleforero" section.

(Cáceres Puro, 1995). The Neogene succession includes upper Miocene and Pliocene intervals, which are bounded by an erosive surface.

The upper Miocene succession (Fig. 2) consists of a coarsening upward sequence from blue mudstones (unit 1) to sandy silts (unit 2) and to sandy facies (units 3, 4, and 5). The sandier interval lies at different localities and includes finegrained glauconitic sands (unit 3), medium- to coarse-grained sands with carbonate concretions (unit 4), and medium- to coarse-grained sands with abundant invertebrate shells (unit 5). The stratigraphic correlation between these units is not clear but it seems that at least 3 and 4 could be partly lateral equivalents. Available chronostratigraphic data for these units is restricted to the sandy units on the top. $\mathrm{K} / \mathrm{Ar}$ radiometric dating of glauconite in unit 3 yielded ages of $6.6 \pm 0.3$ and 6.7 \pm 0.3 Ma (Galán et al., 1993; Mayoral and Muñiz, 1994), which correspond to the Messinian (late Miocene) (Muñiz et al., 2001a, 2001b). Also, bivalves and gastropods in unit 4 seem to indicate a similar age, while calcareous nannoplankton from the same unit corresponds to biozone CN9 sensu Okada and Burky (1980), which is upper Tortonian-Messinian (Muñiz et al., 2001b). The dating of unit 5, from which the material of Podocallichirus laepaensis new species comes, is more obscure. While calcareous nannoplankton correspond to the biozone CN11 sensu Okada and Burky (1980) (late Zanclean) (Muñiz et al., 2001b), the well-preserved malacofauna contains a number of species present in the Miocene Mediterranean and Atlantic basins but absent in the Pliocene sediments (Muñiz et al., 2010).

The Pliocene part of the Neogene succession (Fig. 2) crops out mainly in the interior part west of Lepe. Mapping revealed an erosional boundary between the Miocene and the Pliocene units (Muñiz et al., 2001a, b). The Pliocene succession begins with an erosive boundary on top of unit 5 . This surface is covered by a unit consisting of medium- and coarse-grained sands and reddish gravels and conglomerates with intercalated lenses of white clay (unit 6). This is overlain by a sandy unit (unit 7), which grades into white sandy silts (unit 8). The 


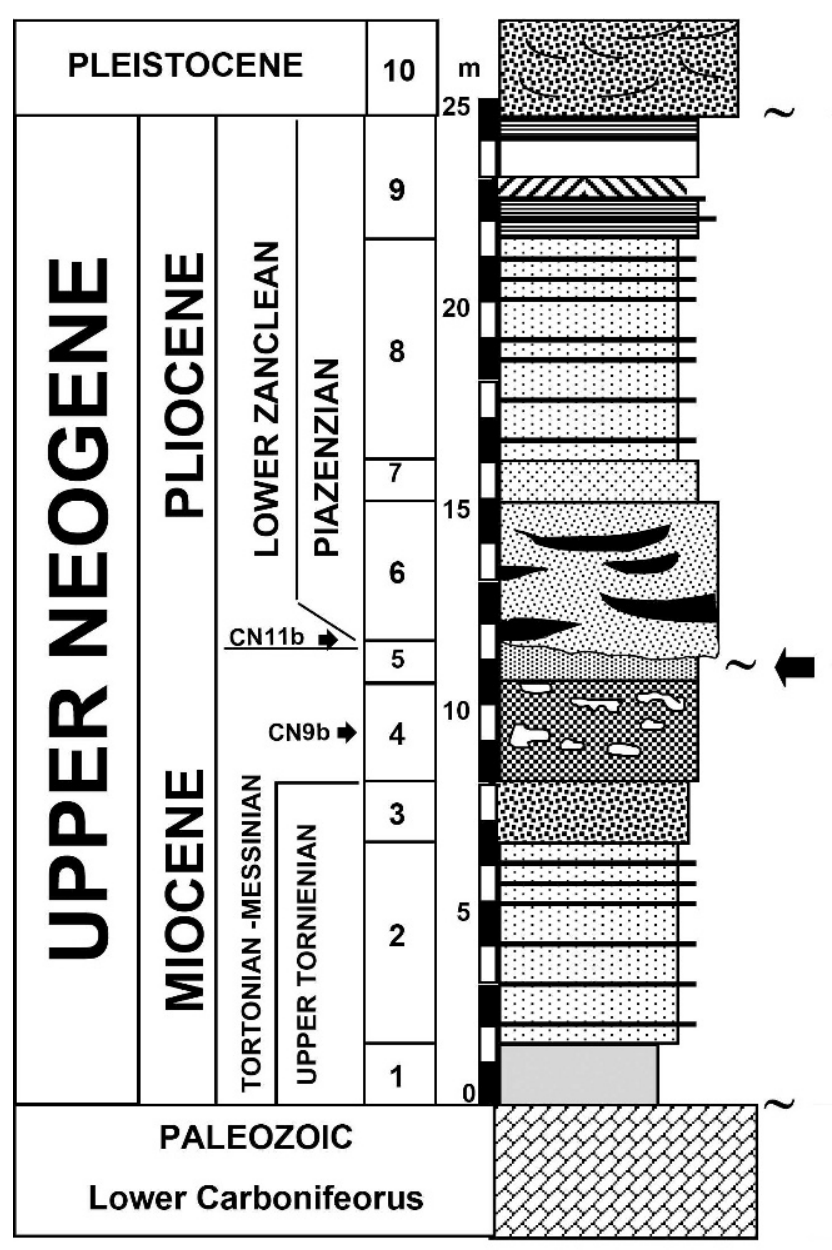

Conglomerates

Medium to coarse sands and caolinitics sands

Silty sands with ferruginous crusts

Medium to coarse sands and sandy arenites

Coarse to very coarse sands, gravels, conglomerates with interbedded clays

\begin{tabular}{|c|c|}
\hline & Medium to coarse sands \\
\hline 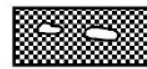 & $\begin{array}{l}\text { Medium to coarse sands with } \\
\text { carbonate nodules }\end{array}$ \\
\hline 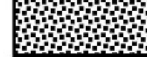 & Glauconitic sands \\
\hline
\end{tabular}

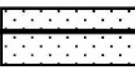

Sandy silts with ferruginous crusts

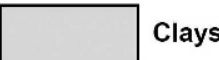

$303 \times 3 \times 1$

Shales and Graywacke in a Culm facies

$\sim$ Discordance

Podocallichirus laepaensis sp. nov.

Figure 2-The Neogene succession of the 'Lepe White Silts'. Podocallichirus laepaensis n. sp. originates from the unit 5 (black arrow).

Pliocene succession culminates with unit 9, medium- to coarsegrained sands, silts and kaolinitic sands (Galan et al., 1993). The Pliocene age of these units is constrained by the presence of late Zanclean nannoplankton in the underlying unit 5 and by the early Pleistocene age of the overlying fluvial gravels. Thus, a middle-late Pliocene age seems the most reasonable for this succession (Muñiz et al., 2010).

Paleoenvironmental and depositional evolution of the LepeAyamonte sector in Neogene.-The Neogene deposits of the Lepe-Ayamonte area indicate the persistence of marginal marine conditions (Muñiz, 1998). The Miocene succession began after a generalized transgression during the Tortonian (Muñiz et al., 2001a). During this interval sedimentation was dominantly silty (unit 2) in a marine infralittoral setting, probably partly restricted, such as a confined bay, affected by periodic small eustatic pulses, which may have even resulted in exposure in an intertidal setting. Glauconitic sands at the top of the sequence could correspond to the maximum transgression (Mayoral and Muñiz, 1996a; Muñiz, 1998; Muñiz et al., 1998; Muñiz and Mayoral, 2001).

Following these deposits, there is a significant stratigraphic hiatus including at least part of the Messinian and the Zanclean (Muñiz, 1998; Muñiz et al., 1998). The overlying unit, probably Piazenzian in age, overlies an erosional surface. This resulted in paleorelief with the Miocene units forming a
SW-NE paleohigh, which confined the sector where Pliocene sedimentation took place. The units of Pliocene age consist of an array of facies that suggest an estuarine system (Muñiz and Mayoral, 1998) with tidal and fluvial influence under subtropical climate conditions (Mayoral and Muñiz, 1996b; Barrón et al., 2003).

Neogene decapod faunas of Spain.-Miocene and Pliocene decapod crustacean associations of Spain have been reported by several authors. For summarizing works of the Miocene decapods of Catalonia references are made to works of Solé and Vía Boada (1989) and Müller (1993). Recently, Artal (2008) reported the presence of the ocypodid Uca Leach, 1814 from the middle Miocene of the same area.

The Miocene and Pliocene decapods of the Guadalquivir Basin are poorly known. Mayoral et al. (1998) described decapod associations from the lower Pliocene of the Guadalquivir Basin. This paper is the first report of an upper Miocene decapod crustacean from the respective area.

\section{MATERIAL AND METHODS}

Material comes from unit 5 of the section "Valleforero" (Muñiz, 1998). It is composed mostly of isolated dactyli and fragmented fixed fingers of major chelae. A limited number of carpi, meri, and propodi have also been found (see Fig. 3 for terms describing the cheliped elements). Material comes from 


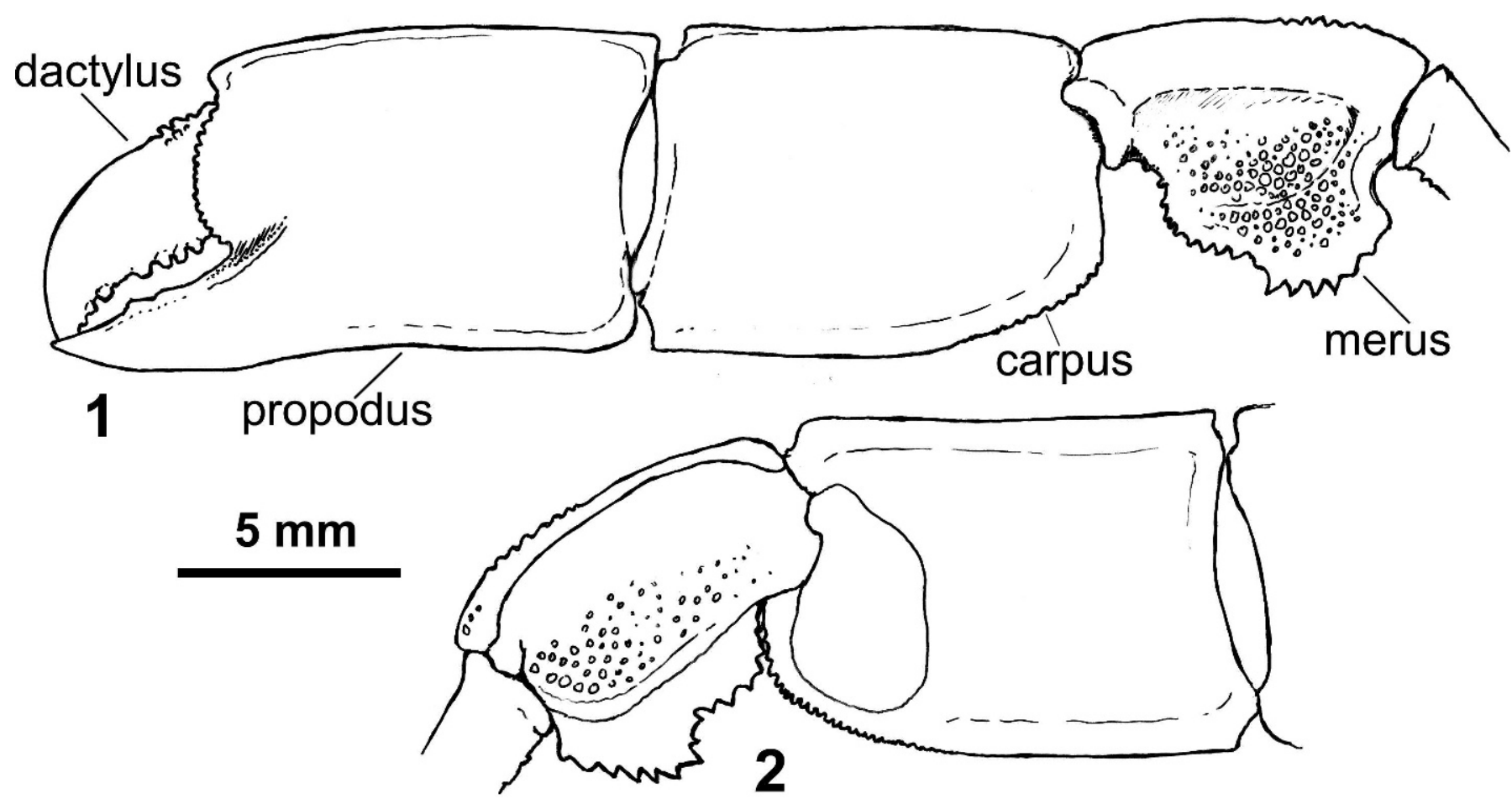

Figure 3-Podocallichirus masoomi (Tirmizi, 1970), Qeshm Island, Persian Gulf, Iran, deposited under number NHMW 24990. 1, major left cheliped from lateral view; 2, major left cheliped (merus and carpus) from mesial view. Note the shape of meral blade and tuberculation on both, lateral and mesial, surfaces.

unconsolidated sandstone and tends to disintegrate. Before study it was impregnated with the adhesive solution Herkules. Specimens were studied with a Leica EZ4 binocular microscope. To enhance contrast the material was coated with ammonium chloride prior the photography.

Comparisons with the extant members of the genera Neocallichirus, Sergio, and Podocallichirus were based mostly upon published figures and descriptions as discussed in the systematic paleontology section of the paper. Additionally, extant specimens of Neocallichirus calmani (Nobili, 1904) (NHMW 6780), $N$. grandimanus (Gibbes, 1850) (NHMW 19826), N. karumba (Poore and Griffin, 1979) (NHMW 21937), Podocallichirus masoomi (Tirmizi, 1970) (NHMW 24990) (Fig. 3) and Sergio mirim (Rodrigues, 1971) (NHMW 6753) deposited in NHMW were also examined for comparative purposes.

Institutional abbreviations. $-\mathrm{CBG} / \mathrm{CD}=$ Centro para la difusión e investigación de la Biodiversidad y geodiversidad, Ciudad de Lepe (Center for diffusion and research of biodiversity and geodiversity, City of Lepe), Spain; KGP$\mathrm{MH}=$ Department of Geology and Paleontology, Comenius University, Bratislava, Slovakia; NHMW=Department of Zoology, Naturhistorisches Museum in Wien, Austria.

\section{SYSTEMATIC PALEONTOLOGY}

Currently, the biological classification of ghost shrimps is in flux. In general, there are several different views on the evaluation of taxonomically important characters as exemplified by works of Biffar (1971), Manning and Felder (1991), Poore (1994, 2008), and Sakai (1999, 2005, 2011). Paleontological literature usually emphasizes the contribution of Manning and Felder (1991). In this context the discussion on the assignment of the callianassoid fossil remains to respective genera in recently published papers (Schweitzer-Hopkins and Feldmann, 1997; Schweitzer and Feldmann, 2002; Schweitzer et al., 2006a, 2006b; Vega et al., 2007; Hyžný and Schlögl, 2011;
Hyžný and Karasawa, 2012; Hyžný and Hudáčková, 2012) further develops the ideas of Manning and Felder (1991). The higher classification follows De Grave et al. (2009).

Order DECAPODA Latreille, 1802

Infraorder AXIIDEA de Saint Laurent, 1979

Family CALlianassidae Dana, 1852

Subfamily CALLICHIRINAE Manning and Felder, 1991 PODOCALLICHIRUS Sakai, 1999

Type species.-Callianassa madagassa Lenz and Richters, 1881.

Remarks.-The present status of the genus Podocallichirus is rather confusing. It was erected by Sakai (1999) to accomodate several species previously mostly treated as Callichirus sensu Le Loeuf and Intés (1974). Poore (2000) erected the genus Grynaminna to accommodate the new species G. tamakii. Grynaminna is similar to Neocallichirus and Sergio, but it differs in the nature of antennae, uropods, and pleopods (Poore, 2000, p. 151). Grynaminna lacks the meral hook on the major cheliped and possesses non-tapering chelipeds. It was considered a junior synonym of Podocallichirus by Sakai (2005). Later Sakai (2011) recognized Grynaminna as a separate genus and divided Podocallichirus into four new additional genera: Balsscallichirus, Barnardcallichirus, Forestcallichirus and Tirmizicallichirus. Podocallichirus remained monotypic containing only its type species, Callianassa madagassa Lenz and Richters, 1881. The recognition of the above mentioned genera can be considered as obscure, as they are based on variable characters which may change during ontogeny, i.e., first two pairs of male pleopods. Biffar (1971, p. 643) previously mentioned that callianassid juveniles lack the characteristic shape of the adult appendages. Intraspecific variability in the shape of the first two male pleopods in the genus Neocallichirus was reported by several 

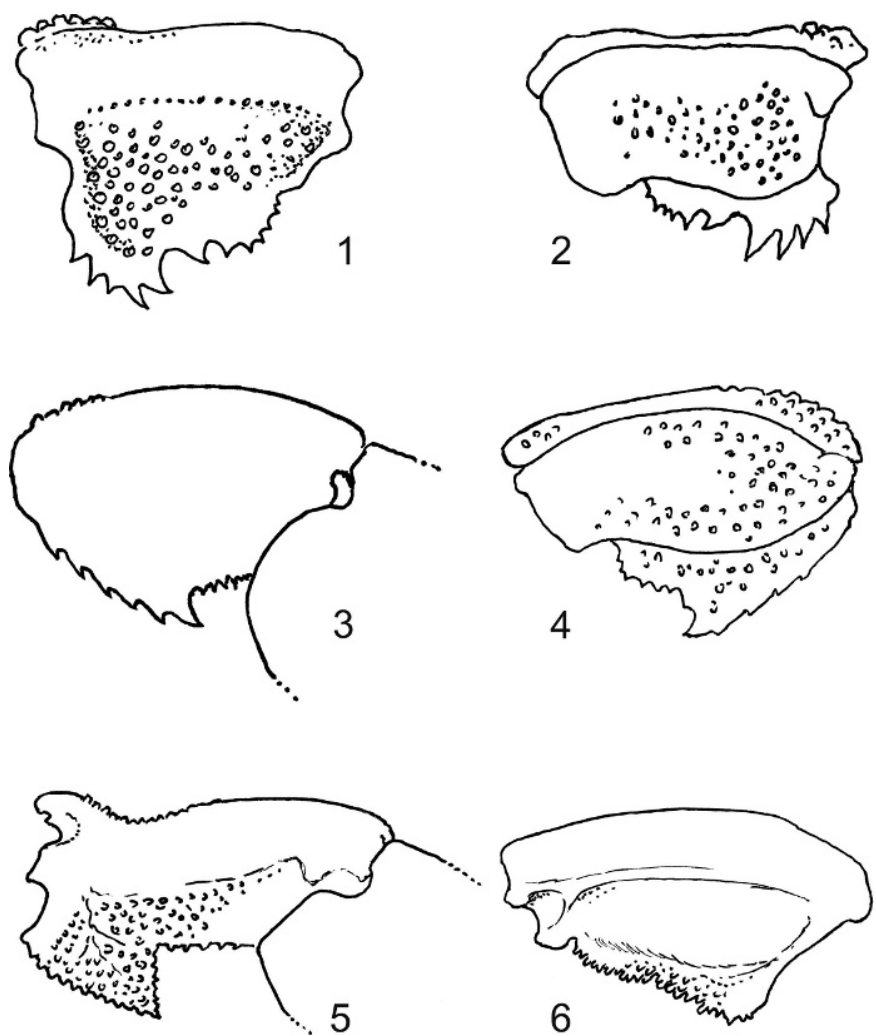

FIGURE 4-Major cheliped merus in selected extant callichirine taxa. 1 , 2. Podocallichirus masoomi (Tirmizi, 1970), in lateral and dorsomesia view, respectively; after Sankolli (1971, figs. 7b, d); 3, Podocallichirus gilchristi (Barnard, 1947), lateral view; after Sakai (1999, fig. 9c); 4, Podocallichirus gilchristi, mesial view; after Barnard (1950, fig. 95b); 5 , Callichirus major (Say, 1818), lateral view; after de Man (1928, fig. 14a); 6, Glypturoides trilobatus (Biffar, 1970), lateral view; after Portell and Agnew (2004, pl. 2, fig. F). authors (Felder and Manning, 1995; Dworschak, 2008, 2011a, 2011b).

For the aims of this contribution, the classification of Sakai (1999) is followed in recognizing seven species of the genus Podocallichirus, although the nature of the genus itself is far from being resolved. We agree with recognizing Grynaminna as a separate genus. The issue on recognizing Podocallichirus sensu Sakai, 1999 in the fossil record was recently discussed by Hyžný and Karasawa (2012).

The best generic assignment of the studied material seems to be identifying it as a member of Podocallichirus based on major similarities between the studied material and two extant Podocallichirus species: P. masoomi (=Callianassa kewalramanii Sankolli, 1971) and P. gilchristi (Barnard, 1947). Sakai (2011) classified the species within Tirmizicallichirus and Barnardcallichirus, respectively. Studied material shares with these species similarly shaped meri (Fig. 5.5-5.7) with distinct triangular hooks; pronounced tuberculation present on both, lateral and mesial surfaces of merus; fixed finger distinctly shorter than palm; and armature of dactylus (Barnard, 1950; Tirmizi, 1970; Sankolli, 1971; Sakai, 1999).

A similarly shaped merus with distinctly broad meral hook is present also in Callichirus, notably in Callichirus major (Say, 1818) as figured by several authors (de Man 1928, fig. 14; Rodrigues, 1971, fig. 11; Manning and Felder, 1986, fig. 1c; Portell and Agnew, 2004, pl. 1, fig. E). In this taxon, however, the merus is distinctly longer than high (Fig. 4.5) and not ovoid as it is in the studied material. Moreover, the morphology of the propodus in C. major is also different.

In other respects Podocallichirus laepaensis n. sp. is close to Neocallichirus (notably to N. audax de Man, 1911; Neocallichirus frouini Ngoc-Ho, 2005; and N. mauritianus Miers, 1882) and Glypturoides Sakai, 2011. Neocallichirus audax (de Man, 1928, fig. 31c, 31d; Rao and Kartha, 1967, fig. 2A) and Glypturoides trilobatus (Biffar, 1970) (Portell and Agnew, 2004, pl. 2, figs. D, E) have fixed finger with rows of tubercles not dissimilar from studied material. Neocallichirus frouini

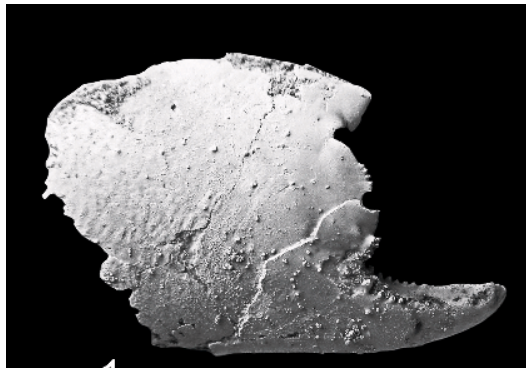

1

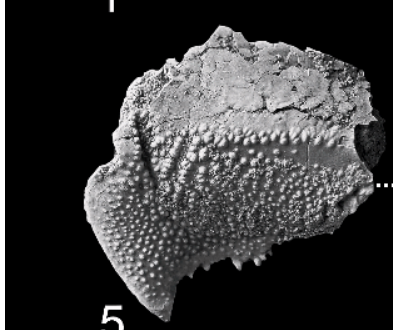

5

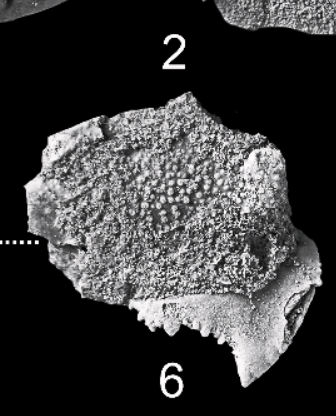

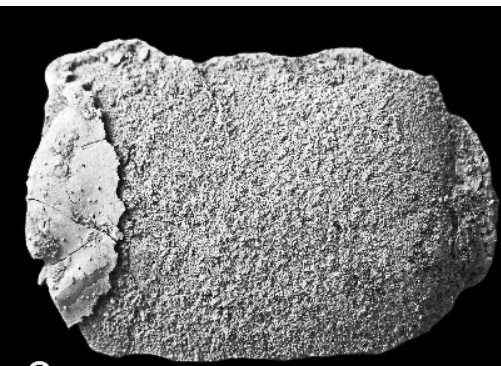

.

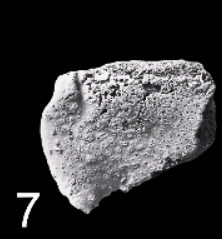

\section{7}

FIGURE 5-Podocallichirus laepaensis n. sp., isolated major cheliped elements. 1, right propodus, paratype CBG/CD/002; 2, left propodus with the broken fixed finger, paratype $\mathrm{CBG} / \mathrm{CD} / 004 ; 3$, right fragmentary propodus articulated with dactylus, paratype $\mathrm{CBG} / \mathrm{CD} / 003$; 4 , left carpus, paratype $\mathrm{CBG} / \mathrm{CD} / 006 ; 5,6$, right merus, holotype $\mathrm{CBG} / \mathrm{CD} / 001 ; 7$, right fragmentary merus, KGP-MH LE-001; 8, 9, right ischium, in mesial and lateral views, respectively, paratype $\mathrm{CBG} / \mathrm{CD} / 005 ; 10$, right fragmentary ischium, lateral view, $\mathrm{CBG} / \mathrm{CD} / 074$. All specimens were coated with ammonium chloride prior to photography. 


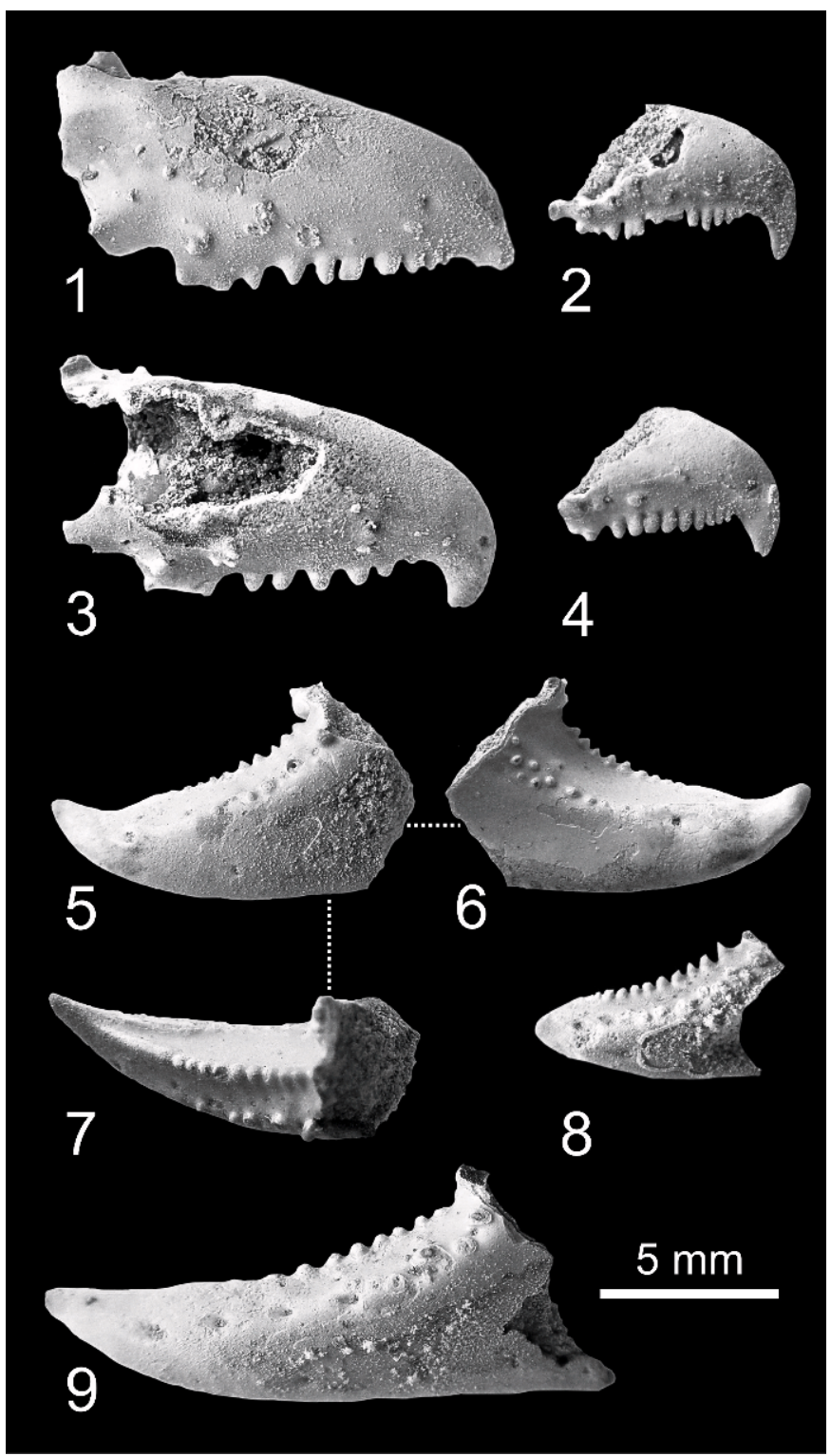

FIGURE 6-Podocallichirus laepaensis $\mathrm{n}$. sp., isolated fingers. 1, right dactylus, paratype $\mathrm{CBG} / \mathrm{CD} / 010$; 2, right dactylus, paratype $\mathrm{CBG} / \mathrm{CD} /$ $037 ; 3$, right dactylus, paratype $\mathrm{CBG} / \mathrm{CD} / 029 ; 4$, right dactylus, paratype CBG/CD/038; 5-7, left fixed finger, in outer view, mesial view, occlusal margin view, respectively, paratype $\mathrm{CBG} / \mathrm{CD} / 064 ; 8$, left fixed finger, paratype $\mathrm{CBG} / \mathrm{CD} / 067$; 9, left fixed finger, paratype $\mathrm{CBG} / \mathrm{CD} / 041$. All specimens were coated with ammonium chloride prior the photography.

(Ngoc-Ho, 2005, fig. 14C), N. mauritianus (de Man, 1928, fig. 4b) and G. trilobatus (Biffar, 1970, fig. 1h; Portell and Agnew, 2004, pl. 2, fig. F; see also Fig. 4.6) have also similarly shaped meri, but none of them is morphologically close to the above mentioned Podocallichirus species.

Considering all these similarities and assuming that the morphology of the merus is usually consistent with the genus concept based on the soft part morphology, as shown by Manning and Felder (1991), we classify studied material within Podocallichirus sensu Sakai (1999). This assignment should be considered preliminary until more complete material is recovered and the generic assignment of the morphologically closest extant taxa ( $P$. masoomi, $P$. gilchristi) is resolved.

The only fossil representative of Podocallichirus listed by Schweitzer et al. (2010) as Podocallichirus grandis (Karasawa and Goda, 1996) was recently reconsidered to be a member of Grynaminna (Hyžný and Karasawa, 2012). The latter authors gave details about the taxonomic history of this taxon. Following their work the present material can be considered to represent the only known fossil representative of Podocallichirus.

\section{PODOCALLICHIRUS LAEPAENSIS new species Figures 5.1-5.10, 6.1-6.9}

Diagnosis.-Callichirine ghost shrimp with robust major cheliped; merus ovoid with distinct keel on the lateral surface, lower part strongly tuberculated; lower margin of merus denticulated with well developed meral hook, meral hook denticulated distally; propodus longer than high, lower margin of propodus slightly concave at the base of fixed finger; fixed finger shorter than palm with three rows of tubercles on its occlusal margin, mesial row longest; dactylus with distinctly hooked tip, occlusal margin with molariform tooth followed with numerous peg-shaped teeth.

Description.-Major cheliped robust with strongly tuberculated proximal elements.

Ischium longer than high, highest near the articulation with merus, slightly sinuous; lateral surface with longitudinal furrow extending along midline and dividing the element into two parts, the lower half tuberculated; mesial surface strongly tuberculated virtually over its entire extent, tubercles fading away distally; the proximal half of the lower margin serrated with tiny denticles, larger denticles positioned more distally; upper margin rather smooth, not well preserved. Merus ovoid with well developed meral blade (or lobe) and distinct proximal hook; lateral surface with longitudinal keel dividing the element into two parts; lower part strongly tuberculated; mesial surface strongly tuberculated, mesial surface of the hook smooth; lower margin denticulated with uneven spines; meral hook strongly convex and smooth proximally, denticulated distally; upper margin not well preserved. Carpus not well preserved, seems to be slightly higher than long, with rounded lower margin; lateral surface smooth. Propodus longer than high, slightly converging distally; lateral surface of palm (manus) smooth; distal margin rounded and serrated; lower margin slightly concave at the base of the fixed finger. Fixed finger shorter than palm, triangular in shape, distinctly longer than high, the tip pointing slightly upward; three rows of tubercles present on the occlusal margin, one of them positioned medially, two of them positioned laterally at the mesial and lateral edges of the occlusal margin, median row with 10 to 20 denticles, lateral row extending to the articulation with dactylus. Dactylus longer than high, usually with distinct hook at its tip; upper surface with several tubercles proximally near the articulation with propodus; lateral surface smooth or with few tubercles proximally; occlusal margin with long bilobed molariform tooth followed with usually up to 10 peg-shaped teeth, teeth becoming smaller distally.

Minor cheliped unknown.

Variations.-The material shows variation in the nature of cheliped fingers. On the fixed finger the variation comprises mainly the differences in number of tubercles in the lateral, medial, and mesial rows (Fig. 6.7). Interestingly, distinctly shorter (and usually smaller) fixed fingers in general have more tubercles (up to 20 in the medial row) which are more peg-shaped (Fig. 6.8), whereas in longer (and usually larger) fixed fingers these are less numerous (around 10 in the medial row) and are more rounded (Fig. 6.9). This variation seems to 

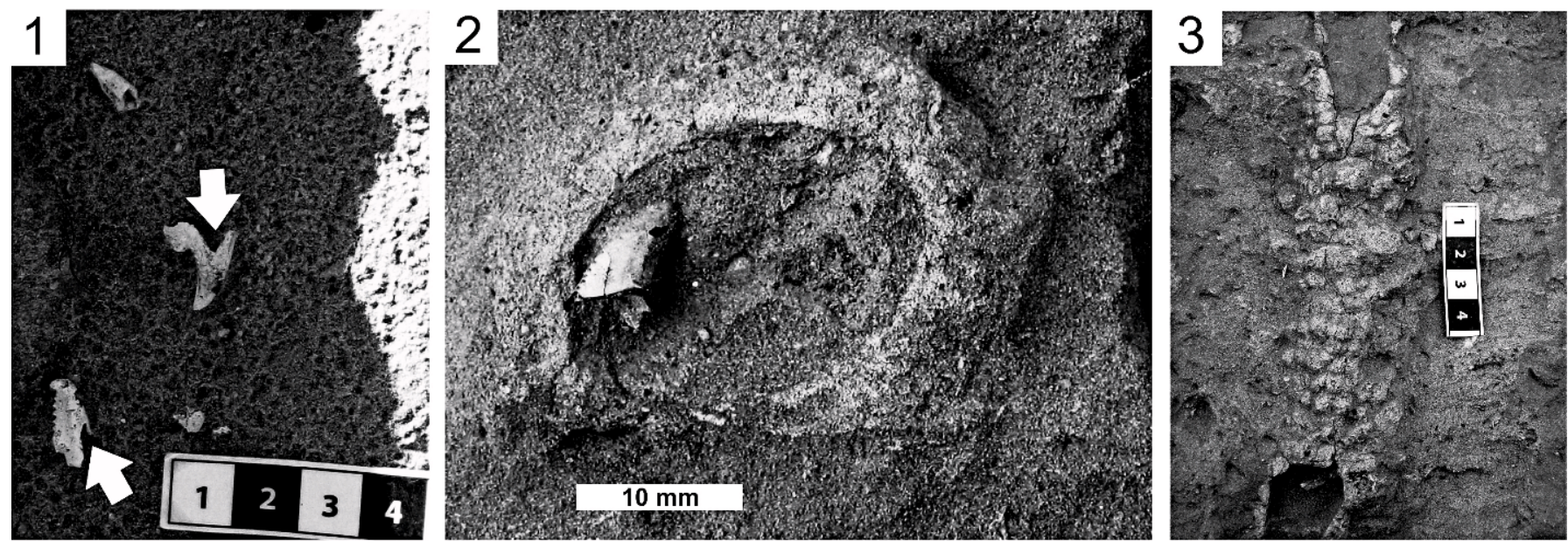

FIGURE 7-Field photographs from the "Valleforero" section. 1, isolated fingers of Podocallichirus laepaensis n. sp., note V-shaped reentrants on the proximal region of the fingers; 2, horizontal cross-section of Ophiomorpha nodosa Lundgren, 1891 with fixed finger of $P$. laepaensis in the internal filling; 3, Ophiomorpha nodosa exhibiting a strongly developed pelletal lining.

be associated with growth: in larger individuals the tubercles fade away distally.

On dactyli, a similar phenomenon can be observed: smaller specimens have numerous teeth on the occlusal margin (up to 20) (Fig. 6.2, 6.4). Their average number is around 10; the spaces between them are larger if the tooth number is lower (Fig. 6.1, 6.3). The shape of teeth is generally rounded, sometimes there are also bifid teeth positioned proximally. The proximal molariform tooth may be subdivided into two blunt teeth (Fig. 6.1).

Variation also can be observed in the way the hooked tip of the dactylus is developed. In some specimens (usually with lower number of teeth on the occlusal margin) the tip is moderately hooked (Fig. 6.1). In other specimens the tip is hooked at a right angle and is distinctly longer than the teeth on the occlusal margin (Fig. 6.2, 6.4). Transitional forms between both morphotypes are also present; thus, we do not interpret the variations in terms of sexual dimorphism.

Etymology.-From the Latin Laepa refering to the town of Lepe.

Types.-The holotype is a nearly complete right merus of major cheliped (CBG/CD/001) (Fig. 5.5, 5.6). The paratype collection consists of a nearly complete right propodus (CBG/ $\mathrm{CD} / 002$ ), a fragmentary left propodus with articulated dactylus (CBG/CD/003), a nearly complete fragmentary left propodus (CBG/CD/004), a complete right ischium (CBG/CD/005), a nearly complete left carpus $(\mathrm{CBG} / \mathrm{CD} / 006)$, four complete or nearly complete right dactyli (CBG/CD/010, CBG/CD/029, $\mathrm{CBG} / \mathrm{CD} / 037, \mathrm{CBG} / \mathrm{CD} / 038)$, and three fragmented left fixed fingers (CBG/CD/041, CBG/CD/064, CBG/CD/067) (Figs. 5, 6).

Other material.-Numerous (several hundred) additional cheliped elements of fragmentary nature deposited under numbers $\mathrm{CBG} / \mathrm{CD} / 007-009$, CBG/CD/011-028, CBG/CD/ 030-36, CBG/CD/039-040, CBG/CD/042-063, CBG/CD/065066, CBG/CD/068-075, CBG/CD/076 (collective number), KGP-MH LE-001-007 and KGP-MH LE-009-010 have been examined. The overwhelming majority of the material represents major cheliped fingers (isolated dactyli and fixed fingers).

Occurrence.-Medium- to coarse-grained sands (unit 5), Valleforero section (Muñiz, 1998), Lepe (Huelva, SW Spain). Podocallichirus laepaensis n. sp. is known from the type locality only.

Remarks.-Podocallichirus laepaensis has direct morphological affinities to its supposed congeners, Podocallichirus masoomi and $P$. gilchristi. No fossil callianassid shrimp identified so far shares the shape of the major cheliped merus with $P$. laepaensis. The character combination, specifically tubercle rows on the fixed finger, peg-shaped teeth on the occlusal margin of dactylus and the shape and ornamentation of merus, readily distinguishes $P$. laepaensis from all fossil callianassids described to date.

Mayoral et al. (1998) reported several cheliped fragments classified as Callianassa sp. from the lower Pliocene of Guadalquivir Basin. They figured one fragmented propodus articulated with a dactylus (Mayoral et al., 1998, fig. 2.1). The overall morphology of this specimen clearly points to its identity as a laomediid, Jaxea Nardo, 1847. Indeed, at the same place remains of Jaxea nocturna Nardo, 1847 were also found (Mayoral et al., 1998; Hyžný, 2011b).

\section{NOTES ON TAPHONOMY}

Taphonomy and preservation of burrowing shrimps were discussed at length by Bishop and Williams (2005). They distinguished several types of resulting fossils in accordance of their preservation (Bishop and Williams, 2005, fig. 2). In this respect the material of Podocallichirus laepaensis n. sp., which is virtually entirely of an isolated and fragmented nature, can be classified as cheliped elements. No disassociation unit sensu Bishop and Williams (2005), a natural aggregation of exoskeleton elements preserved together, has been found. In decapod crustacean disarticulation, fragmentation, and decay are generally rapid (Schäfer, 1972; Plotnick 1986; Plotnick et al., 1988; Stempien, 2005; Krause et al., 2011), and this is highlighted in callianassid shrimp possessing a weakly calcified exoskeleton (except chelipeds). The strength of the cuticle in brachyurous crabs varies within the exoskeleton parts and throughout the growth cycle of the animal (Mutel et al., 2008; Waugh et al., 2009). The same can be postulated for burrowing shrimps.

Interestingly, the studied material shows a mode of preservation similar to that discussed by Mutel et al. (2008). Their experiments with deploying crabs on the sea bottom can be compared with the fossil record where the preservation of isolated fingers is much the same, thus, exhibiting a specific pattern of degradation. Remains of P. laepaensis show Vshaped reentrants on the proximal region of the fingers (Figs. 6.3, 6.8, 6.9, 7.1), which are virtually identical with 
those in deployed crabs reported by Mutel et al. (2008, figs. 3B, 3D, 5B, 7A, 7B) and Krause et al. (2011, fig. 4C).

The fragmentary nature of $P$. laepaensis at the studied section can be attributed to a high bioturbation rate in the area. The cheliped fragments of $P$. laepaensis have been found in association with the trace fossil Ophiomorpha nodosa Lundgren, 1891 (Fig. 7.3). Podocallichirus laepaensis is suspected to be the potential tracemaker of these traces. Cheliped fragments can be found all around the trace fossils, some of them have been found within a burrow (Fig. 7.2). Direct connection between Ophiomorpha traces and callianassid shrimps was previously demonstrated by Weimer and Hoyt (1964) and discussed by Frey et al. (1978). Bishop and Williams (2005, p. 225) stated that "the direct occurrence of fossil thalassinoids within trace fossil burrows is unusual but occasionally has been reported or figured." More recent discussion on this issue can be found in Neto de Carvalho et al. (2007), Buatois and Mángano (2011) and Hyžný (2011a).

\section{ACKNOWLEDGMENTS}

Special thanks are owed P. C. Dworschak (Natural History Museum, Wien, Austria) for access to the collection of extant callianassid shrimps deposited at NHMW and fruitful discussions, and R. M. Feldmann (Kent State University, Ohio, U.S.A.) for improving the English of the manuscript. The manuscript benefited from constructive reviews by R. M. Feldmann and H. Karasawa (Mizunami Fossil Museum, Gifu, Japan) and editorial comments by S. Hageman. The research of MH was supported by grants APVV 0280-07 to D. Reháková (Comenius University, Bratislava, Slovakia), KEGA K-09-009-00 to N. Hudáčková (Comenius University, Bratislava, Slovakia), and Comenius University Grant UK/ 168/2011 and PalSIRP Sepkoski Grant 2011 to MH. The research of FM was supported by the Lepe Town Council and the Grupo de Investigación RNM 316 "Tectónica y Paleontología" of the University of Huelva, Spain.

\section{REFERENCES}

Abad, M., E. M. Mantero, M. CAMacho, R. Martín-BAnda, AND M. CANTANO. 2005. Estructuras post-sedimentarias en el margen noroccidental de la Cuenca del Guadalquivir (Niebla, Candón, Valverde del Camino), SO de España. Geogaceta, 37:203-206.

ARTAL, P. 2008. Uca miocenica (Crustacea, Decapoda), nueva especies del Mioceno de la Prov. de Barcelona (Cataluña, España). Scripta Musei Geologici Seminarii Barcinonensis, Series Palaeontologica, 6:3-16.

Baceta, J. I. AND J. G. Pendón. 1999. Estratigrafía y arquitectura de la Formación Niebla, Neógeno superior, sector oriental de la cuenca del Guadalquivir. Revista de la Sociedad Geológica de España, 12:419438

BARNARD, K. H. 1947. Descriptions of new species of South African decapod Crustacea, with notes on synonymy and new records. The Annals and Magazine of Natural History, series 11, 13(for 1946):361392.

BARNARD, K. H. 1950. Descriptive catalogue of South African decapod Crustacea (crabs and shrimps). Annals of the South African Museum, 38:1-837.

BARRÓN, E., F. MUÑIZ, AND E. MAYORAL. 2003. Aspectos macrofloristicos del Plioceno de Lepe (Cuenca del Guadalquivir, Huelva, España): consideraciones Paleoecológicas. Boletín de la Real Sociedad Española de Historia Natural (Sección Geología), 98:91-109.

BIFFAR, T. A. 1970. Three new species of callianassid shrimp (Decapoda, Thalassinidea) from the western Atlantic. Proceedings of the Biological Society of Washington, 83:34-50.

BIFFAR, T. A. 1971. The genus Callianassa (Crustacea, Decapoda, Thalassinidea) in south Florida, with keys to the Western Atlantic species. Bulletin of Marine Science, 21:637-715.

Bishop, G. A. AND A. B. WiLliams. 2005. Taphonomy and preservation of burrowing thalassinidean shrimps. Proceedings of the Biologica Society of Washington, 118:218-236.

Braga, J. C., J. M. Martin, And C. Quesada. 2003. Patterns and average rates of late Neogene-Recent uplift of the Betic Cordillera, SE Spain. Geomorphology, 50:3-26.
Buatois, L. And G. MÁngano. 2011. Ichnology. Organism-Substrate interactions in Space and Time. Cambridge University Press, Cambridge, $370 \mathrm{p}$.

CÁCERES PuRO, L. M. 1995. Geomorfología del sector occidental de la Depresión del Guadalquivir (Huelva). Unpublished Ph.D. dissertation, Universidad de Huelva, $250 \mathrm{p}$.

Civis, J., F. J. Sierro, J. A. González Delgado, J. A. Flores, I. ANDrÉs, J. D. Porta, AND M. F. VAlle. 1987. El Neógeno marino de la provincia de Huelva. Antecedentes y definición de las unidades litoestratigráficas. Studia Geologica Salmanticensia, Special volume (Paleontología del Neógeno de Huelva):9-21.

DanA, J. D. 1852. Conspectus Crustaceorum. Conspectus of the Crustacea of the Exploring Expedition under Capt. Wilkes, U.S.N. Macroura. Proceedings of the Academy of Natural Sciences of Philadelphia, 6:10-28.

De Grave, S., N. D. Pentcheff, S. T. Ahyong, T.-Y. Chan, K. A. Crandall, P. C. Dworschak, D. L. Felder, R. M. Feldmann, C. H. J. M. Fransen, L. Y. D. Goulding, R. Lemaitre, M. E. Y. Low, J. W. Martin, P. K. L. NG, C. E. Schweitzer, S. H. TAN, D. Tshudy, AND R. WETZER. 2009. A classification of living and fossil genera of decapod crustaceans. The Raffles Bulletin of Zoology, Supplement 21:1-109.

DworschaK, P. C. 2000. Global diversity in the Thalassinidea (Decapoda). Journal of Crustacean Biology, 20:238-245.

DWORSCHAK, P. C. 2005. Global diversity in the Thalassinidea (Decapoda): an update (1998-2004). Nauplius, 13:57-63.

DworschaK, P. C. 2008. Neocallichirus kempi Sakai, 1999, a junior synonym of Callianassa karumba Poore and Griffin, 1979 (Decapoda: Callianassidae). Raffles Bulletin of Zoology, 56:75-84.

DWORSCHAK, P. C. 2011a. Redescription of Callianassa jousseaume Nobili, 1904, a junior [sic!] subjective synonym of Callianassa indica de Man, 1905 with description of a new species of Neocallichirus (Decapoda: Axiidea: Callianassidae). Zootaxa, 2746:1-19.

DWORSCHAK, P. C. 2011b. Redescription of Callianassa vigilax de Man, 1916, a subjective synonym of Neocallichirus denticulatus Ngoc-Ho, 1994 (Crustacea: Decapoda: Callianassidae). Annalen des Naturhistorischen Museums in Wien, B112:137-151.

FELDER, D. L. AND R. B. MANNING. 1995. Neocallichirus cacahuate, a new species of ghost shrimp from the Atlantic coast of Florida, with reexamination of $N$. grandimana and $N$. lemaitrei (Crustacea: Decapoda: Callianassidae). Proceedings of the Biological Society of Washington, 108:477-490

Frey, R. W., J. D. HowARD, AND W. A. PRYOR. 1978. Ophiomorpha: its morphologic, taxonomic, and environmental significance. Palaeogeography, Palaeoclimatology, Palaeoecology, 23:199-229.

Galán, E., I. GonZÁlez, E. Mayoral, AND F. MuÑIz. 1993. Contribution of clay mineralogy to the paleoenvironmental interpretation of upper Miocene detrital sediments. Euroclay'95, Leuven, Abstracts, 1:311-312.

GIBBES, L. R. 1850. On the carcinological collections of the cabinets of natural history in the United States with an enumeration of the species contained therein, and description of new species. Proceedings of the American Association for the Advancement of Science, 3rd meeting, $p$ $167-201$.

HYŽNÝ, M. 2011a. In situ mud shrimps (Decapoda: Axiidea: Callianassidae) preserved within their burrows from the middle Miocene of the Central Paratethys. Bulletin of the Mizunami Fossil Museum, 37:37-46.

HYŽNÝ, M. 2011b. Revision of Jaxea kuemeli Bachmayer, 1954 (Decapoda: Gebiidea: Laomediidae) from the Miocene of Europe, with remarks on the palaeobiogeography of the genus Jaxea Nardo, 1847. Neues Jahrbuch für Geologie und Paläontologie Abhandlungen, 260:173-184.

HYŽNÝ, M. AND N. HudÁČKOVÁ. 2012. Redescription of two ghost shrimps (Decapoda: Axiidea: Callianassidae) from the Middle Miocene of the Central Paratethys: systematics, intraspecific variation, and in situ preservation. Zootaxa, 3210:1-25.

HYŽNYY, M. AND H. KARASAWA. 2012. How to distinguish Neocallichirus, Sergio, Podocallichirus and Grynaminna (Decapoda: Callianassidae: Callichirinae) from each other in the fossil record? Bulletin of the Mizunami Fossil Museum, 38:55-64.

HYŽNÝ, M. AND J. SCHLÖGL. 2011. An early Miocene deep-water decapod crustacean faunule from the Vienna Basin (Western Carpathians, Slovakia). Palaeontology, 54:323-349.

KARASAWA, H. AND T. GODA. 1996. Two species of decapod crustaceans from the Middle Pleistocene Atsumi Group, Japan. Scientific Reports of the Toyohashi Museum of Natural History, 6:1-4.

Krause JR., R. A., K. Parsons-Hubbard, and S. E. Walker. 2011 Experimental taphonomy of a decapod crustacean: Long-term data and their implications. Palaeogeography, Palaeoclimatology, Palaeoecology, 312:350-362. 
LATReille, P. A. 1802-1803. Histoire naturelle, générale et particulière des Crustacés et des Insectes. Vol. 3. F. Dufart, paris, 468 p.

LEACH, W. E. 1814. Crustaceology, p. 385-437. In D. Brewster (ed.), Edinburgh Encyclopaedia, 7(2), Baldwin, London.

LE LoeufF, P. AND A. Intès. 1974. Les Thalassinidea (Crustacea, Decapoda) du Golfe de Guinée systématique-écologie. Cahiers de l'Office de Recherches Scientifiques et Techniques Outre Mer, série Océanographique, 12:17-69.

LENZ, H. AND F. RichteRs. 1881. Beitrag zur Crustaceenfauna von Madagascar. Abhandlungen der Senckenbergischen Naturforschenden Gesellschaft, 12:421-428.

LundGREN, S. A. B. 1891. Studier öfver fossilörande lösa block. Geologiska Föreningens i Stockholm Förhandlingar, 13:111-121.

MAN, J. G. DE. 1911. On two new species of decapod Crustacea. Notes from the Leyden Museum, 33:223-232.

Man, J. G. DE. 1928. The Decapoda of the Siboga-Expedition. Pt. 7. The Thalassinidae and Callianassidae collected by the Siboga-Expedition with some remarks on the Laomediidae. Siboga Expéditie, 39(A6):1187.

Manning, R. B. AND D. L. Felder. 1986. The status of the callianassid genus Callichirus Stimpson, 1866 (Crustacea: Decapoda: Thalassinidea). Proceedings of the Biological Society of Washington, 99:437-443.

Manning, R. B. AND D. L. Felder. 1991. Revision of the American Callianassidae (Crustacea: Decapoda: Thalassinidea). Proceedings of the Biological Society of Washington, 104:764-792.

Manning, R. B. AND R. LemaitRe. 1994. Sergio, a new genus of ghost shrimp from the Americas (Crustacea: Decapoda: Callianassidae) Nauplius, 1:39-43.

Mayoral, E., P. Müller, And F. MuÑIz. 1998. Lower Pliocene decapod crustaceans from the southwestern Iberian Peninsula (Guadalquivir basin, Sevilla, Spain). Geobios, 31:505-510.

MAYORAL, E. AND F. MUÑIZ. 1994. Presencia de un nuevo cefalópodo sepioideo en el Neógeno superior de la Cuenca del Guadalquivir, (Lepe, Huelva, España). Coloquios de Paleontología, 46:161-174.

MAYORAL, E. AND F. MUÑIZ. 1996a. La Icnofacies de Gnathichnus en el sector Suroccidental de la Cuenca del Guadalquivir (Lepe, Huelva, España). Coloquios de Paleontología, 48:71-82.

MAYORAL, E. AND F. MuÑIZ. 1996b. Tafonomía de las Pistas fósiles y su aplicación en las reconstrucciones paleoambientales del Neógeno marino de Lepe (Huelva). Comunicación de la II Reunión de Tafonomía y Fosilización, Zaragoza, :205-210.

Miers, E. J. 1882. On some Crustaceans collected at the Mauritius. Proceedings of the Scientific Meetings of the Zoological Society of London, 1882:339-342.

MÜLLER, P. 1993. Neogene decapod crustaceans from Catalonia. Scripta Musei Geologici Seminarii Barcinonensis, 225:1-39.

MuÑIZ, F. 1998. Paleoicnología del Neógeno Superior en el Sector Suroccidental de la Cuenca del Guadalquivir, Área de Lepe-Ayamonte (Huelva). Unpublished Ph.D. dissertation, Universidad de Huelva, $272 \mathrm{p}$.

MuÑz, F., J. M. DE Gibert, E. MAyoral, ANd Z. Belaústegui. 2010 Introduction to the Geology of the Lepe Area, p. 3-8. In F. Muñiz, J. M. de Gibert, E. Mayoral, and Z. Belaústegui (eds), Fieldtrip Guidebook Workshop on Crustacean Bioturbation-Fossil and Recent, Huelva.

MuÑIZ, F. ANd E. Mayoral. 1998. Paleoichnology of the lower Pliocene estuarine facies in the SW sector of the Guadalquivir basin (LepeAyamonte area, Huelva, Spain). 1st Interdisciplinary Symposium on Estuarine Processes, Faro, Portugal, Abstracts, 1:72-76.

MuÑIZ, F. AND E. MAYORAL. 2001. El icnogénero Spongeliomorpha en el Neógeno Superior de la Cuenca del Guadalquivir (Área de LepeAyamonte, Huelva, España). Revista Española de Paleontología, 16:115-130.

Muñiz, F., E. Mayoral, L. M. CÁceres, AND M. CAChão. 2001a Correlación entre las unidades litoestratigráficas del Neógeno superior en el sector suroccidental de la Cuenca del Guadalquivir. Geogaceta, 30:239-241.

Muñiz, F., E. Mayoral, L. M. CÁCeres, And M. CAChão. 2001b. Nuevos datos bio-cronoestratigráficos para el sector suroccidental de la Cuenca del Guadalquivir (área de Lepe-Ayamonte, Huelva, España). Geogaceta, 30:243-244

MuÑIZ, F., E. MAYORAL, AND J. A. GÁmez VinTANED. 1998. Icnofacies del Neógeno superior de la Cuenca del Guadalquivir (área de LepeAyamonte, Huelva, España). Geogaceta, 24:235-238.

Mutel, M. H. E., D. A. Waugh, R. M. Feldmann, and K. M. PARSONS-HUBBARD. 2008. Experimental taphonomy of Callinectes sapidus and cuticular controls on preservation. Palaios, 23:615-623.

NARDO, G. D. 1847. Sinonimia moderna delle specie registrate nell' opera intitolata: Descrizone de' Crostacei, de' Testacei e de' Pesci che abitano le Lagune e Golfo Veneto, rappresentati in figure, a chiaro-scuro ed a colori dall' Abate Chiereghini Ven (Clodiense applicata per commissione governativa). Venezia, xi, $127 \mathrm{p}$.

Neto de Carvalho, C., P. A. Viegas, and M. Cachão. 2007. Thalassinoides and its producer: populations of Mecochirus buried within their burrow systems, Boca do Chapim Formation (Lower Cretaceous), Portugal. Palaios, 22:104-109.

NGOC-Ho, N. 2003. European and Mediterranean Thalassinidea (Crustacea, Decapoda). Zoosystema, 25:439-555.

NGOC-Ho, N. 2005. Thalassinidea (Crustacea, Decapoda) from French Polynesia. Zoosystema, 27:47-83.

NoBiLI, G. 1904. Diagnoses préliminaires de vingt-huit espèces nouvelles de Stomatopodes et Décapodes Macroures de la Mer Rouge. Bulletin du Muséum d'Histoire naturelle, Paris (1. Série), 10(5):228-238.

OKADA, H. AND D. BURKY. 1980. Supplementary modification and introduction of code numbers to the low-latitude cocolith biostratiraphic zonation (Bukry, 1973, 1975). Marine Micropaleontology, 5:321325.

Pendón, J. G., F. Ruíz, M. Abad, M. L. González-Regalado, J. I. BACETA, AND J. TOSQUELLA. 2004. Transgressive sequences on foreland margins; a case study of the Neogene central Guadalquivir Basin, southern Spain. Rivista Italiana di Paleontología e Stratigrafia, 110:503-515.

PLOTNICK, R. E. 1986. Taphonomy of a modern shrimp: implications for the arthropod fossil record. Palaios, 1:286-293.

Plotnick, R. E., T. BAumiller, and K. Wetmore. 1988. Fossilization potential of the mud crab Panopeus (Brachyura: Xanthidae) and time dependence in crustacean taphonomy. Palaeogeography, Palaeoclimatology, Palaeocology, 63:27-43.

Poore, G. C. B. 1994. A phylogeny of the families of Thalassinidea (Crustacea: Decapoda) with keys to families and genera. Memoirs of Museum Victoria, 54:79-120.

Poore, G. C. B. 2000. A new genus and species of callianassid ghost shrimp from Kyushu, Japan (Decapoda: Thalassinidea). Journal of Crustacean Biology, 20:150-156.

Poore, G. C. B. 2008. Thalassinidean shrimps (Crustacea: Decapoda) from north-western Australia, including five new species. Records of the Western Australian Museum, Supplement 73:161-179.

Poore, G. C. B. AND D. J. G. GRIFFIN. 1979. The Thalassinidea (Crustacea: Decapoda) of Australia. Records of the Australian Museum, 32:217-321.

Portell, R. W. and J. G. Agnew. 2004. Pliocene and Pleistocene decapod crustaceans. Florida Fossil Invertebrates, 4:1-29.

RAO, P. V. AND K. N. R. KARTHA. 1967. On the occurrence of Callianassa (Callichirus) audax De Man (Crustacea Decapoda Callianassidae) on the southwest coast of India with a description of male. Marine Biological Association of India, Symposium, Cochin, Abstracts, 1:279 284.

Rodrigues, S. DE A. 1971. Mud shrimps of the genus Callianassa Leach from the Brazilian coast (Crustacea, Decapoda). Arquivos de Zoologia, 20:191-223.

SAINT LAURENT, L. DE. 1979. Vers une nouvelle classification des Crustacés Décapodes Reptantia. Bulletin de l'Office National des Pêches République Tunisienne, Ministere de l'Agriculture, 3:15-31.

SAKAI, K. 1988. A new genus and five new species of Callianassidae (Crustacea: Decapoda: Thalassinidea) from Northern Australia. The Beagle, Records of the Northern Territory Museum of Arts and Sciences, 5:51-69.

SAKAI, K. 1999. Synopsis of the family Callianassidae, with keys to subfamilies, genera and species, and the description of new taxa (Crustacea: Decapoda: Thalassinidea). Zoologische Verhandelingen (Leiden), 326:1-152.

SAKAI, K. 2005. Callianassoidea of the world (Decapoda: Thalassinidea) Crustaceana Monographs, 4:1-285.

SAKAI, K. 2011. Axioidea of the World and a Reconsideration of the Callianassoidea (Decapoda, Thalassinidea, Callianassida). Crustaceana Monographs, 13:1-520.

SAnkolli, K. N. 1971. The Thalassinoidea (Crustacea, Anomura) of Maharashtra. Journal of the Bombay Natural History Society, 68:94-106.

Sanz De Galdeano, C. 1990. Geologic evolution of the Betic Cordilleras in the western Mediterranean, Miocene to the present. Tectonophysics, $172: 107-119$

SAY, T. 1818. An account of the Crustacea of the United States. Pt. 5. Journal of the Academy of Natural Sciencies, Philadelphia, 1:235-253.

SCHÄFER, W. 1972. Ecology and Palaeoecology of Marine Environments. University of Chicago Press, Chicago, $568 \mathrm{p}$

Schweitzer, C. E. AND R. M. Feldmann. 2002. New Eocene decapods (Thalassinidea and Brachyura) from Southern California. Journal of Crustacean Biology, 22:938-967. 
Schweitzer, C. E., R. M. Feldmann, A. Garassino, H. Karasawa, AND G. SCHWEIGERT. 2010. Systematic list of fossil decapod crustacean species. Crustaceana Monographs, 10:1-222.

Schweitzer, C. E., G. GonzÁlez-Barba, R. M. Feldmann, and D. A. WAugh. 2006a. Decapoda (Thalassinidea and Paguroidea) from the Eocene Bateque and Tepetate Formations, Baja California Sur, México: systematics, cuticle microstructure, and paleoecology. Annals of Carnegie Museum, 74:275-293.

Schweitzer, C. E., M. Iturralde-Vinent, J. L. Hetler, and J. VeleZ-JuARBE. 2006b. Oligocene and Miocene decapods (Thalassinoidea and Brachyura) from the Caribbean. Annals of Carnegie Museum, 75:111-136.

SChweitzer-Hopkins, C. AND R. M. Feldmann. 1997. Sexual dimorphism in fossil and extant species of Callianopsis de Saint Laurent. Journal of Crustacean Biology, 17:236-252.

SIERRO, F. J. 1985. Estudio de los foraminíferos planctónicos, bioestratigrafía y cronoestratigrafía del Mio-Plioceno del borde occidental de la Cuenca del Guadalquivir (SO de España). Studia Geologica Salmanticensia, 21:7-85.

Sierro, F. J., J. A. GonzÁlez-Delgado, J. A. Flores, C. J. Dabrio, AND J. CIVIS. 1990. The Neogene of the Guadalquivir Basin (SW Spain). Paleontologia i Evolución, Memoria Especial, 2:209-250.

Sierro, F. J., J. A. González-Delgado, C. J. Dabrio, J. A. Flores, AND J. CIVIS. 1996. Late Neogene depositional sequences in the foreland basin of Gualdalquivir (SW Spain), p. 339-345. In P. F. Friends and C. Dabrio (eds.), Tertiary Basins of Spain. Cambridge University Press, Cambridge.
SOlÉ, J. AND L. Vía BOADA. 1989. Crustacis decàpodes fòssils dels PaÏsos Catalans (Recopilació i actualització de dades des de 1855 a 1988). Batalleria, 2:23-42.

Stempien, J. A. 2005. Brachyuran taphonomy in a modern tidal-flat environment: Preservation potential and anatomical bias. Palaios, 20:400-410.

STIMPSON, W. 1866. Descriptions of new genera and species of Macrurous Crustacea from the coasts of North America. Proceedings of the Chicago Academy of Sciences, 1:46-48.

TAMAKI, A. (ed). 2004. Proceedings of the Symposium on "Ecology of large bioturbators in tidal flats and shallow sublittoral sediments - from individual behavior to their role as ecosystem engineers.". Marine Research Institite, Nagasaki University, Nagasaki, 118 p.

TIRMIZI, N. M. 1970. A new species of Callianassa (Decapoda, Thalassinidea) from West Pakistan. Crustaceana, 19:245-250.

Vega, F. J., T. Nyborg, A. Rojas-Briceño, P. Patarroyo, J. Luque, H. PoRRAS-MÚZQUIZ, AND W. STINNESBECK. 2007. Upper Cretaceous Crustacea from Mexico and Colombia: similar faunas and evironmnets during Turonian times. Revista Mexicana de Ciencias Geológicas, 24:403-422.

Waugh, D. A.,R. M. Feldmann, J. L. Burrell, A. L. Hull, K. Hein, AND C. E. SCHWEITZER. 2009. Ontogenetic variations in cuticle morphology in the blue crab Callinectes sapidus Rathbun, 1896. Journal of Crustacean Biology, 29:141-156.

Weimer, R. J. AND J. H. Hoyt. 1964. Burrows of Callianassa major Say, geologic indicators of littoral and shallow neritic environments. Journal of Paleontology, 38:761-767.

ACCEPTED 24 FEBRUARY 2012 